\title{
The procoagulant potential of environmental particles $\left(\mathrm{PM}_{10}\right)$
}

\author{
P S Gilmour, E R Morrison, M A Vickers, I Ford, C A Ludlam, M Greaves, K Donaldson, W MacNee
}

Occup Environ Med 2005;62:164-171. doi: 10.1136/oem.2004.014951

See end of article for authors' affiliations .....................

Correspondence to: Prof. W MacNee, ELEGI/ Colt Laboratory, The University of Edinburgh, Wilkie Building, Medical School, Teviot Place, Edinburgh EH8 9AG, UK; w.macnee@ed.ac.uk

Accepted

22 September 2004
Background and Aims: Epidemiology studies have shown that cardiovascular (CV) disease is primarily responsible for the mortality associated with increased pulmonary environmental particle ( $\mathrm{PM}_{10}$ ) exposure. The mechanisms involved in $\mathrm{PM}_{10}$ mediated $\mathrm{CV}$ effects are unknown although changes in plasma viscosity and in the homoeostasis of blood coagulation have been implicated. It was hypothesised that $\mathrm{PM}_{10}$ exposure would result in an inflammatory response and enhance the activation of the extrinsic coagulation mechanisms in pulmonary and vascular cells in culture.

Methods: Primary human monocyte derived macrophages and human umbilical cord vein endothelial, human alveolar type II epithelial (A549), and human bronchial epithelial (16HBE) cells were tested for their inflammatory and procoagulant response to $\mathrm{PM}_{10}$ exposure. IL-8, tissue factor (TF), and tissue plasminogen activator (tPA) gene expression and protein release, and coagulation enhancing ability of culture media were determined 6 and 24 hours following exposure.

Results: The culture media from macrophages and 16HBE bronchial epithelial cells, but not A549 cells, exposed to $\mathrm{PM}_{10}$ had an enhanced ability to cause clotting. Furthermore, $\mathrm{H}_{2} \mathrm{O}_{2}$ also increased the clotting activity. Apoptosis was significantly increased in macrophages exposed to PM 10 and LPS as shown by annexin $V$ binding. TF gene expression was enhanced in macrophages exposed to $P M_{10}$, and HUVEC tissue factor and IPA gene and protein expression were inhibited.

Conclusions: These data indicate that $\mathrm{PM}_{10}$ has the ability to alter macrophage, epithelial, and endothelial cell function to favour blood coagulation via activation of the extrinsic pathway and inhibition of fibrinolysis pathways.
$\mathrm{T}$ here is a strong association between increases in environmental particles $\left(\mathrm{PM}_{2.5}\right.$ and $\left.\mathrm{PM}_{10}\right)$ and adverse effects on pulmonary and cardiovascular health. Pulmonary effects include increased frequency of exacerbations of asthma and chronic obstructive pulmonary disease (COPD), and increased mortality. ${ }^{1}$ Lung cancer deaths are also increased in areas of high particulate pollution. ${ }^{2}$ At concentrations commonly attained in US and European urban areas, ${ }^{134}$ increased levels of particles are also associated with an increased prevalence in cardiovascular exacerbations. ${ }^{25}$ This cardiovascular impact has been suggested to be at least as great as that on respiratory disease despite the latter having a greater relative risk. In one study the respiratory and cardiovascular mortality associated with particulate air pollution increased by $0.54 \%$ and $0.69 \%$ respectively with a rise of $10 \mu \mathrm{g} / \mathrm{m}^{3}$ in $\mathrm{PM}_{10} \cdot{ }^{6}$ Pope and colleagues $^{3}$ found that a $10 \mu \mathrm{g} / \mathrm{m}^{3}$ increase in $\mathrm{PM}_{10}$ concentration was associated with a $1 \%$ increase in daily mortality, a $3.4 \%$ increase in respiratory related mortality, and a $1.8 \%$ increase in cardiovascular related mortality. A comparable increase in $\mathrm{PM}_{2.5}$ was associated with a rise in total and respiratory/cardiovascular mortality of $4 \%$ and $6 \%$ respectively. $^{2}$

The mechanism of the adverse cardiovascular effects caused by inhalation of particulate air pollution remains unclear. We have hypothesised that ultrafine particle mediated lung inflammation could lead to a systemic increase in blood coagulability. ${ }^{7}$ This has been supported by studies during a pollution episode. ${ }^{89}$ Proinflammatory properties of $\mathrm{PM}_{10}$ have been identified in vitro ${ }^{10}{ }^{11}$ and in vivo in healthy volunteers. ${ }^{12}$ There is evidence that $\mathrm{C}$ reactive protein is increased in response to particulate air pollution, ${ }^{9}$ and there are clear links between inflammation and atherothrombosis. It has been suggested that inhaled particles may induce a prothrombotic state, through increased plasma viscosity, ${ }^{8}$ and increased plasma fibrinogen and factor VII concentrations. ${ }^{912}{ }^{13}$ Furthermore, experimental studies have supported an effect of $\mathrm{PM}_{10}$ on the development and progression of atherosclerotic plaque formation and rupture, a process which is central to the pathogenesis of acute arterial thrombotic events. ${ }^{14}$

Identifying pathogenetic mechanisms in models employing healthy animals or in experiments with normal human subjects has been difficult. Stimulation of bone marrow myelopoiesis by particle inhalation has been reported in animal studies, ${ }^{15}{ }^{16}$ confirming a remote systemic effect. ${ }^{13}$ However, in experimental animals blood hypercoagulability has not been noted.

One plausible mechanism to explain particle mediated hypercoagulability is the induction of tissue factor (TF). TF is a cell surface glycoprotein and is a receptor and cofactor for activated factor VII (FVIIa). The formation of a TF:FVIIa complex initiates the extrinsic blood coagulation pathway. This is regarded now as the key route to thrombin generation in vivo and is activated in tissue damage and inflammation. TF expression can be induced in a number of cell types in response to injury or inflammatory mediators, ${ }^{17}$ including vascular endothelial ${ }^{18}$ and epithelial cells ${ }^{19}$ and macrophages. ${ }^{20}$ TF:FVIIa expression on the cell surface is regulated by TF gene expression and the availability of anionic phospholipids $^{21}$ such as those present on the surface of

Abbreviations: ARDS, adult respiratory distress syndrome; COPD, chronic obstructive pulmonary disease; $\mathrm{CV}$, cardiovascular; $\mathrm{HBE}$, human bronchial epithelial; HUVEC, human umbilical vein endothelial cell; IL, interleukin; LPS, lipopolysaccharide; PAI, plasminogen activator inhibitor; PM, particulate matter; TF, tissue factor; TNF, tumour necrosis factor; $\mathrm{PAA}$, tissue plasminogen activator 
apoptotic cells. ${ }^{22}$ Anionic phospholipids themselves promote coagulation by acting as a template for the assembly of the tenase and prothrombinase complexes, which facilitates the generation of thrombin. ${ }^{23}$

Inhibition of the fibrinolytic pathway results in a prothrombotic state, also. Efficient thrombus lysis requires the activation of plasminogen to plasmin. This is principally through the action of tissue plasminogen activator (tPA). The activity of tPA is regulated by plasminogen activator inhibitor 1 (PAI-1). Alterations in the balance between tPA and PAI-1 have been associated with inflammatory states such as pneumonia, ${ }^{24}$ sepsis, $^{25}$ and adult respiratory distress syndrome (ARDS). ${ }^{26}$

Vascular endothelial cells have an enhanced procoagulant activity and impaired fibrinolytic ability in lung conditions such as sepsis, acute lung injury, ${ }^{27}$ and the post-operative state. $^{28}$ Therefore we hypothesise that generation of procoagulant activity and/or inhibition of fibrinolysis in the lung and in the pulmonary microvasculature may play a role in the cardiovascular effects of $\mathrm{PM}_{10}$.

In order to explore the possibility that $\mathrm{PM}_{10}$ can induce prothrombotic changes in human macrophages, endothelial cell and pulmonary epithelial cell prothrombotic and fibrinolytic responses to $\mathrm{PM}_{10}$ exposure were investigated.

\section{MATERIALS AND METHODS}

Reagents

All chemicals used in this study were obtained from Sigma Chemical Co., Poole, UK. Cell culture media and reagents were obtained from Gibco-BRL, Paisley, UK. Human recombinant TNF $\alpha$ (R\&D Systems, Abingdon, UK) was stored at $-80^{\circ} \mathrm{C}$ at a concentration of $10 \mu \mathrm{g} / \mathrm{ml}$ in sterile distilled water and was diluted in culture media to $10 \mathrm{ng} / \mathrm{ml}$ for use. Hydrogen peroxide $\left(\mathrm{H}_{2} \mathrm{O}_{2}\right)$ was prepared in a stock solution of $2 \mathrm{mM}$ in phosphate buffered saline (PBS) and experiments were carried out at a final concentration of $200 \mu \mathrm{M}$. Lipopolysaccharide (LPS) was prepared at $1 \mathrm{mg} / \mathrm{ml}$ in $\mathrm{dH}_{2} \mathrm{O}$, stored at $-80^{\circ} \mathrm{C}$, and used in cell exposures at a final concentration of either 1 or $10 \mu \mathrm{g} / \mathrm{ml}$. Staurosporine was stored at $-20^{\circ} \mathrm{C}$ at $10 \mu \mathrm{g} / \mathrm{ml}$ and used at a final concentration of $10 \mathrm{ng} / \mathrm{ml}$.

\section{Cell culture}

Human lung type II alveolar-like epithelial cells (A549) and human bronchial epithelial cells (16HBE) were cultured in Dulbecco's modified Eagle's Medium (DMEM) supplemented with $10 \%$ heat inactivated fetal calf serum (FCS), Lglutamine $(2 \mathrm{mM})$, and penicillin/streptomycin solution in $5 \% \mathrm{CO}_{2}$ at $37^{\circ} \mathrm{C}$ as previously described..$^{10}$

Human peripheral blood monocyte derived macrophages were isolated as previously described. ${ }^{11}$ Briefly, $40 \mathrm{ml}$ whole blood was collected from healthy volunteers into $50 \mathrm{ml}$ Falcon tubes containing sodium citrate anticoagulant and sedimented with $6 \%$ dextran 500 . The leucocyte rich layer was carefully removed and the mononuclear fraction isolated using an isotonic discontinuous PBS/Percoll gradient (Amersham Pharmacia Biotech, Bucks, UK) by centrifugation. The monocytes were collected from the Percoll gradient, washed in PBS, and were seeded into 24 well plates at a density of 4 million cells per $\mathrm{ml}$ in RPMI medium containing L-glutamine $(2 \mathrm{mM})$ and penicillin/streptomycin solution without serum, and incubated at $37^{\circ} \mathrm{C}$ in $5 \% \mathrm{CO}_{2}$. After one hour, the medium was removed along with non-adherent cells, the monocytes washed, and the medium replaced with RPMI medium containing $10 \%$ autologous serum obtained from the donor during the cell isolation process. The monocytes were matured for five days into macrophages with media changes every two days.
Human umbilical vein endothelial cells (HUVECs) were isolated as previously described. ${ }^{29}$ Briefly, fresh human umbilical veins were washed with PBS (without $\mathrm{Ca}^{2+}$ and $\mathrm{Mg}^{2+}$ ), filled with pre-warmed $0.05 \%$ collagenase solution, and incubated at $37^{\circ} \mathrm{C}$ for 6 minutes. Thereafter the veins

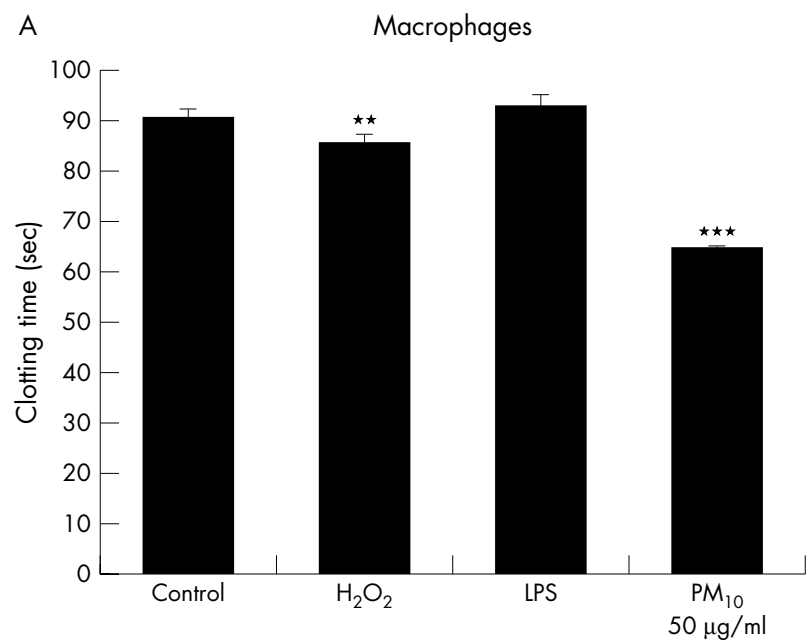

B

A549

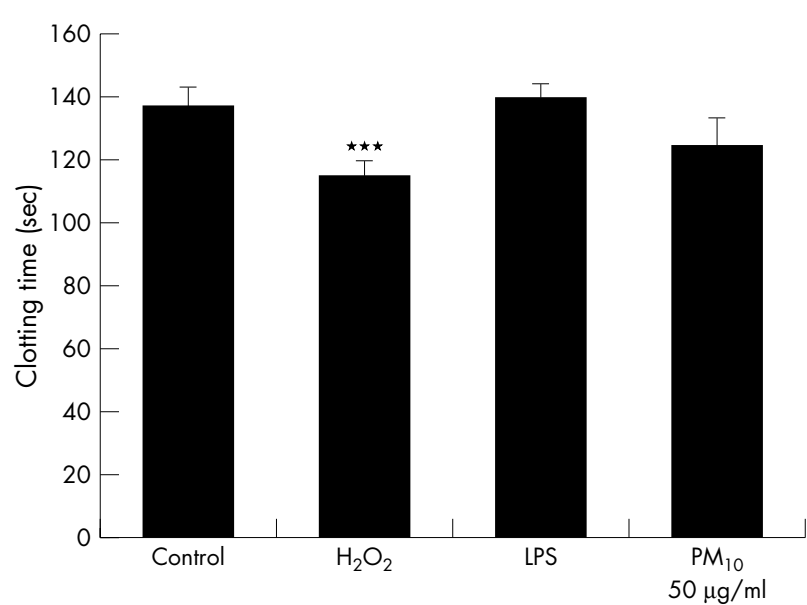

C

$16 \mathrm{HBE}$

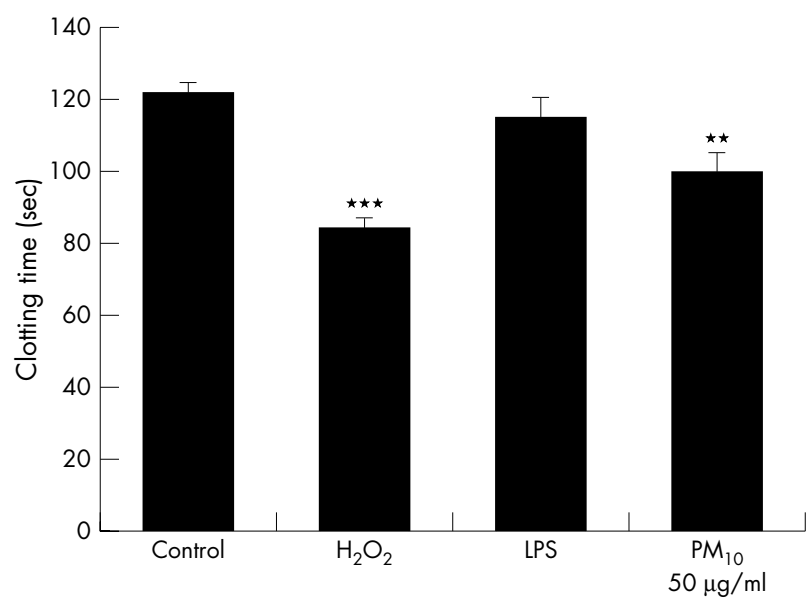

Figure 1 Clotting activity of supernatants of $(\mathrm{A})$ macrophages, $(\mathrm{B})$ A549, and (C) $16 \mathrm{HBE}$ cells treated with $\mathrm{PM}_{10}(50 \mu \mathrm{g} / \mathrm{ml}), \mathrm{H}_{2} \mathrm{O}_{2}$ $(100 \mu \mathrm{M})$, and LPS $(1 \mu \mathrm{g} / \mathrm{ml})$ for 20 hours. Each bar represents the mean (SEM) from at least three separate experiments. ${ }^{*} p<0.05$, ${ }^{* *} p<0.01,{ }^{* * *} p<0.001$. 
were perfused with PBS to harvest cells. Cells were collected from the perfusate by centrifugation at $1000 \mathrm{rpm}$ for 5 minutes; isolated, pelleted cells were resuspended and cultured in EGM endothelial cell medium (Clonetics, Wokingham, UK) containing all enclosed supplements (including $2 \% \mathrm{v} / \mathrm{v}$ fetal bovine serum but without gentamicin), and grown in $175 \mathrm{~cm}^{3}$ culture flasks.

\section{Cell exposures}

Cells were plated at a density of $0.15 \times 10^{6}$ cells/well in 24 well plates and grown overnight until $80 \%$ confluent. The medium was removed from the cultures and was replaced with serum free medium for a further 24 hours incubation. Test compounds were added for specified times (see results) in serum free medium.

\section{Particles}

Carbon black, which was used in the determination of $\mathrm{PM}_{10}$ concentration, was obtained from Degussa Ltd, Frankfurt, Germany.

Particulate matter, of which $50 \%$ was $<10 \mu \mathrm{m}$ diameter $\left(\mathrm{PM}_{10}\right)$ was obtained, quantified, and used as previously described..$^{10}$ Briefly, $\mathrm{PM}_{10}$ particles were collected on filters in the tapered element oscillating micro-balance of the Marylebone and Bloomsbury, London, monitoring sites of the United Kingdom enhanced urban network. To deliver $\mathrm{PM}_{10}$ into solution, filters were cut in half and each was sonicated into $1 \mathrm{ml}$ of PBS for 1 minute, vortex mixed, and the half-filter removed. Particle concentration was determined by spectrophotometric comparison with a standard curve of turbidity at $340 \mathrm{~nm}$. As well as estimating the dose of $\mathrm{PM}_{10}$, the use of carbon black in the standard curve allowed the dose to be standardised relative to a toxicologically important component of $\mathrm{PM}_{10}$. All $\mathrm{PM}_{10}$ cell exposures were carried out at a concentration of $50 \mu \mathrm{g} / \mathrm{ml} \mathrm{PM} \mathrm{PM}_{10}$ in culture medium unless indicated otherwise in results.

\section{Effects of cell culture supernatants on the recalcification time of citrated human plasma}

A $100 \mu \mathrm{l}$ aliquot of culture supernatant was added to the same volume of normal human plasma pool and mixed at $37^{\circ} \mathrm{C}$. A $100 \mu \mathrm{l}$ aliquot of $25 \mathrm{mM}$ calcium chloride was added, and the time measured for a visible clot to form while manually tipping the tube periodically from the waterbath was noted. Manchester Reagent rabbit brain thromboplastin was used as a positive control and phosphate buffered saline as a negative control. Control experiments were also

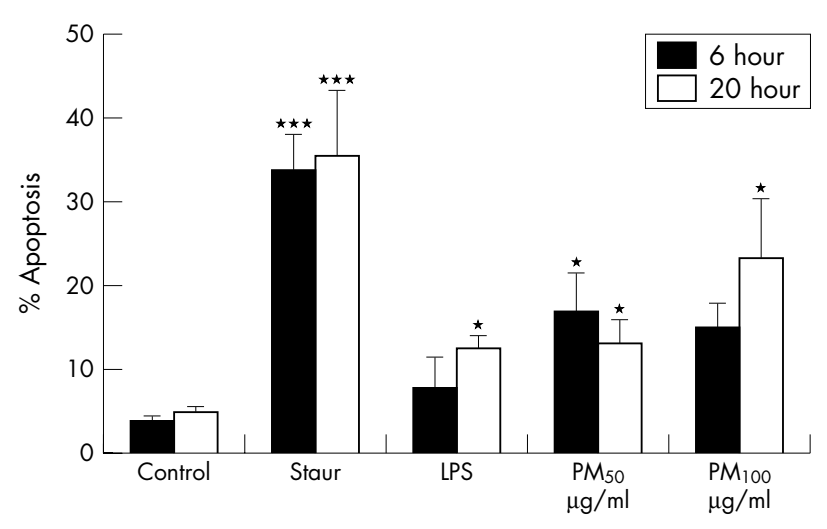

Figure 2 Percentage macrophages binding annexin $\mathrm{V}$ following 6 and 20 hours treatment with $\mathrm{PM}_{10}(50$ and $100 \mu \mathrm{g} / \mathrm{ml}), \mathrm{H}_{2} \mathrm{O}_{2}(100 \mu \mathrm{M})$, and LPS $(1 \mu \mathrm{g} / \mathrm{ml})$ as measured by Caspatag staining and counting. Each bar represents the mean (SEM) from at least three separate experiments. ${ }^{*} p<0.05,{ }^{* * *} p<0.001$.

performed which excluded any direct effect of particles on clotting times.

\section{Reverse transcriptase polymerase chain reaction (RT-PCR)}

After exposure to test materials, RNA was isolated from PBS washed cells using the TRIzol reagent (Gibco-BRL, Paisley, Scotland), according to the manufacturer's instructions, and dissolved in $50 \mu \mathrm{l}$ diethylpyrocarbonate (DEPC) treated water. Moloney murine leukemia virus reverse transcriptase (M-MLV RT) (Promega, Southampton, UK) was used to transcribe cDNA from $2 \mu \mathrm{g}$ mRNA according to the manufacturer's instructions. The genes investigated were the housekeeping gene glyceraldehyde-3-phosphate dehydrogenase (GAPDH), interleukin-8 (IL-8), tissue factor, and tPA with the primer oligonucleotides purchased from MWGBiotech (Milton Keynes, UK). The following primer pairs were used: GAPDH, sense 5'-CCA CCC ATG GCA AAT TCC ATG GCA-3', and antisense 5'-TCT AGA CGG CAG GTC AGG TCC ACC-3'; IL-8, sense 5'-CGA TGT CAG TGC ATA AAG ACA-3', and antisense 5' -TGA ATT CTC AGC CCT CTT CAA AAA-3'; tissue factor, sense $5^{\prime}$-CCC TGA ATT TGA CAG TCT CAC C-3', and antisense 5'-CAC AAT AAA ACT TGC CCA GAA AAA C-3'; and tPA, sense 5'-GTC TGC TGT GCA CCA TCC CCC ATC-3', and antisense, 5'-TTG TCA TCA ATC TTG AAT CCC ATA-3'. The primers were diluted to $100 \mathrm{pmol} / \mu \mathrm{l}$

Table 1 IL-8 protein release and mRNA expression from macrophages, A549, and 16HBE cells treated with $\mathrm{PM}_{10}(50 \mathrm{\mu g} / \mathrm{ml})$, TNF $\alpha(10 \mathrm{ng} / \mathrm{ml}), \mathrm{H}_{2} \mathrm{O}_{2}(100 \mu \mathrm{M})$, and LPS $(1 \mu \mathrm{g} / \mathrm{ml})$ for 6 and 20 hours

\begin{tabular}{|c|c|c|c|c|c|}
\hline Cell type & Untreated & $\mathrm{PM}_{10}$ & LPS & TNF $\alpha$ & $\mathrm{H}_{2} \mathrm{O}_{2}$ \\
\hline \multicolumn{6}{|l|}{ IL-8 protein (ng/ml) } \\
\hline Macrophage $6 \mathrm{~h}$ & $0.08(0.02)$ & $0.594(0.06)^{* * *}$ & $0.500(0.1)^{\star * *}$ & $0.529(0.07)^{\star * *}$ & $0.299(0.02)^{* * *}$ \\
\hline A549 $6 \mathrm{~h}$ & $0.05(0.01)$ & $0.080(0.006)^{*}$ & $0.053(0.002)$ & $0.807(0.04)^{\star * *}$ & $0.273(0.04)^{* *}$ \\
\hline $16 \mathrm{HBE} 6 \mathrm{~h}$ & $0.30(0.04)$ & $0.50(0.08)^{* *}$ & $0.51(0.07)^{\star * *}$ & $0.75(0.04)^{* * *}$ & $0.64(0.09)^{* * *}$ \\
\hline Macrophage $20 \mathrm{~h}$ & $0.26(0.02)$ & $0.653(0.03)$ & $0.747(0.02)$ & $0.746(0.04)$ & $0.673(0.01)$ \\
\hline A549 $20 \mathrm{~h}$ & $0.24(0.03)$ & $0.370(0.03)$ & $0.323(0.05)$ & $0.875(0.03)$ & $0.491(0.04)$ \\
\hline $16 \mathrm{HBE} 20 \mathrm{~h}$ & $0.51(0.01)$ & $1.061(0.12)$ & $0.825(0.06)$ & $1.116(0.10)$ & $0.941(0.11)$ \\
\hline \multicolumn{6}{|c|}{ IL-8 mRNA (ratio to GAPDH) } \\
\hline Macrophage $6 \mathrm{~h}$ & $0.555(0.12)$ & $1.568(0.3)^{* *}$ & $1.164(0.31)^{\star *}$ & $1.137(0.36)^{\star *}$ & $0.760(0.19)^{*}$ \\
\hline A549 $6 \mathrm{~h}$ & $0.176(0.05)$ & $0.222(0.05)$ & $0.188(0.08)$ & $1.023(0.04)^{\star \star \star}$ & $0.501(0.05)^{\star *}$ \\
\hline $16 \mathrm{HBE} 6 \mathrm{~h}$ & $0.155(0.03)$ & $0.667(0.15)^{* *}$ & $0.933(0.03)^{* *}$ & $0.780(0.23)^{* *}$ & $0.635(0.18)^{\star *}$ \\
\hline Macrophage $20 \mathrm{~h}$ & $0.114(0.07)$ & $0.886(0.22)^{* \star *}$ & $0.783(0.20)^{\star * *}$ & $0.301(0.08)^{\star *}$ & $0.307(0.14)^{\star *}$ \\
\hline A549 $20 \mathrm{~h}$ & $0.093(0.01)$ & $0.290(0.04)^{* *}$ & $0.112(0.02)$ & $1.021(0.16)^{* * *}$ & $0.278(0.04)^{* *}$ \\
\hline $16 \mathrm{HBE} 20 \mathrm{~h}$ & $0.441(0.08)$ & $0.698(0.10)^{*}$ & $0.431(0.11)$ & $1.266(0.11)^{\star \star \star}$ & $0.601(0.21)^{*}$ \\
\hline
\end{tabular}

Each value represents the mean (SEM) from at least three separate experiments. ${ }^{*} \mathrm{p}<0.05,{ }^{* *} \mathrm{p}<0.01,{ }^{* * *} \mathrm{p}<0.001$. 
with DEPC water. For each PCR reaction $5 \mu$ l of reverse transcribed DNA (CDNA) was added directly to a PCR reaction mixture set to a final volume of $50 \mu \mathrm{l}$ containing 1 $\times$ Taq DNA polymerase reaction buffer (Promega, UK), $2.5 \mathrm{mM} \mathrm{MgCl}_{2}, 0.2 \mathrm{mM}$ dNTP mixture, 1 unit Taq DNA polymerase (Promega, UK), and $1 \mu \mathrm{M}$ of the appropriate primer pair. The IL-8 PCR conditions were 27 thermal cycles of $94^{\circ} \mathrm{C}$ for 30 seconds, $60^{\circ} \mathrm{C}$ for 1 minute, and $68^{\circ} \mathrm{C}$ for 2 minutes followed by a final extension step of $68^{\circ} \mathrm{C}$ for 7 minutes, resulting in a product 180 base pairs in size. The conditions for GAPDH were 25 thermal cycles of $94^{\circ} \mathrm{C}$ for 45 seconds, $60^{\circ} \mathrm{C}$ for 45 seconds, and $72^{\circ} \mathrm{C}$ for 1 minute 30 seconds followed by a final extension step of $68^{\circ} \mathrm{C}$ for 7 minutes, resulting in a product 600 base pairs in size. The conditions for tissue factor were 35 thermal cycles of $94^{\circ} \mathrm{C}$ for 1 minute, $65^{\circ} \mathrm{C}$ for 1 minute, and $72^{\circ} \mathrm{C}$ for 1 minute 30 seconds followed by a final extension step of $72^{\circ} \mathrm{C}$ for 7 minutes, resulting in a product 173 base pairs in size. The conditions for tPA were 28 thermal cycles of $94^{\circ} \mathrm{C}$ for 45 seconds, $60^{\circ} \mathrm{C}$ for 45 seconds, and $72^{\circ} \mathrm{C}$ for 1 minute, followed by a final extension step of $72^{\circ} \mathrm{C}$ for 7 minutes, resulting in a product 234 base pairs in size. The resulting amplified DNA fragments were separated by electrophoresis through a $1.5 \%$ agarose gel, and the bands were visualised and scanned by a white/UV transilluminator (Ultra Violet Products, Cambridge, UK) and quantified by densitometry.

\section{Assessment of cell surface exposure of negatively charged phospholipid}

This was determined by analysis of annexin $\mathrm{V}$ binding to macrophages grown on coverslips by fluorescence microscopy. Briefly, monocytes were matured into macrophages, isolated as described above, on coverslips placed in six well cell culture dishes. The cells were treated with $\mathrm{PM}_{10}$, LPS, and staurosporine $(8 \mu \mathrm{M})$ as a positive control for annexin $\mathrm{V}$ binding. After exposure to the test compounds for 4 hours, the cells were washed twice in PBS and then once in the annexin $\mathrm{V}$ binding buffer, $2 \mathrm{mM} \mathrm{CaCl}_{2}$ in HBSS. A drop of annexin V:propidium iodide solution ( $5 \mu \mathrm{l}$ Alexa 488 conjugated annexin-V plus $1 \mu \mathrm{l}$ propidium iodide (both Molecular Probes, Leiden, Netherlands) in $1 \mathrm{ml}$ annexin V binding buffer) was added to the cells on the coverslip. The coverslip was then mounted and sealed onto a microscope slide to prevent drying of stained cells and the slides kept in the dark. The number of positively stained (red) cells was compared to the total number of cells, determined by propidium iodide staining, and expressed as the percentage of annexin $\mathrm{V}$ positive cells.

\section{IL-8, tissue factor, and tPA assay}

IL-8 release was determined by ELISA ${ }^{30}$ using an R\&D Systems (Abingdon, UK) paired IL-8 antibody kit, as previously described. TF and tPA antigens were determined by ELISA (Quadratech Ltd, Epsom, UK) as per the manufacturer's instructions.

\section{Statistical analysis}

The data are expressed as mean (SEM). Differences were evaluated using one way ANOVA followed by Tukey's posthoc test for multigroup comparisons. ${ }^{31}$ Statistical significance is reported when $\mathrm{p}<0.05, \mathrm{p}<0.01$, and $\mathrm{p}<0.001$, and indicated in figures as one, two, or three asterisks, respectively.

\section{RESULTS}

\section{Interleukin-8 gene expression and secretion by} macrophages and epithelial cells

Table 1 presents the results. There was some variation in responses between cell type and agonists. $\mathrm{PM}_{10}$ induced both gene expression and synthesis of IL- 8 by macrophages and 16HBE cells comparable in extent to results with the other agonists. The response of $\mathrm{A} 549$ cells to $\mathrm{PM}_{10}$ was generally less marked.

\section{Effect of $P M_{10}$, oxidative stress, and LPS on procoagulant activity in culture supernatants}

The supernatants from macrophages (fig 1A), A549 cells (fig 1B), and 16HBE cells (fig 1C) treated for 20 hours were examined in the pooled plasma recalcification time assay. $\mathrm{PM}_{10}$, and to a lesser extent $\mathrm{H}_{2} \mathrm{O}_{2}$, significantly reduced the macrophage mediated clotting time (fig lA). Only $\mathrm{H}_{2} \mathrm{O}_{2}$ treatment media reduced the clotting time in the A549 experiments (fig $1 \mathrm{~B}$ ), whereas $\mathrm{H}_{2} \mathrm{O}_{2}$ and $\mathrm{PM}_{10}$ stimulated a clotting reaction in the $16 \mathrm{HBE}$ derived treatment media (fig 1C). LPS treatment supernatants had no significant effect in culture supernatants from all three cell types.

\section{Expression of negatively charged phospholipid by cultured cells}

Annexin binding by macrophages after exposures for 6 and 20 hours was assessed as described in the methods (fig 2). As expected, incubation with staurosporine resulted in a marked increase in annexin $\mathrm{V}$ binding. Four hours treatment with $\mathrm{PM}_{10}$ at $100 \mu \mathrm{g} / \mathrm{ml}$, but not $50 \mu \mathrm{g} / \mathrm{ml}$, significantly increased annexin $\mathrm{V}$ binding. At 20 hours there was a significant increase in binding with both $\mathrm{PM}_{10}$ concentrations and at 20 hours with LPS exposure.

\section{Macrophage tissue factor mRNA expression}

Tissue factor mRNA expression was determined in macrophages treated for 6 and 20 hours with $\mathrm{PM}_{10}, \mathrm{TNF}, \mathrm{H}_{2} \mathrm{O}_{2}$, and

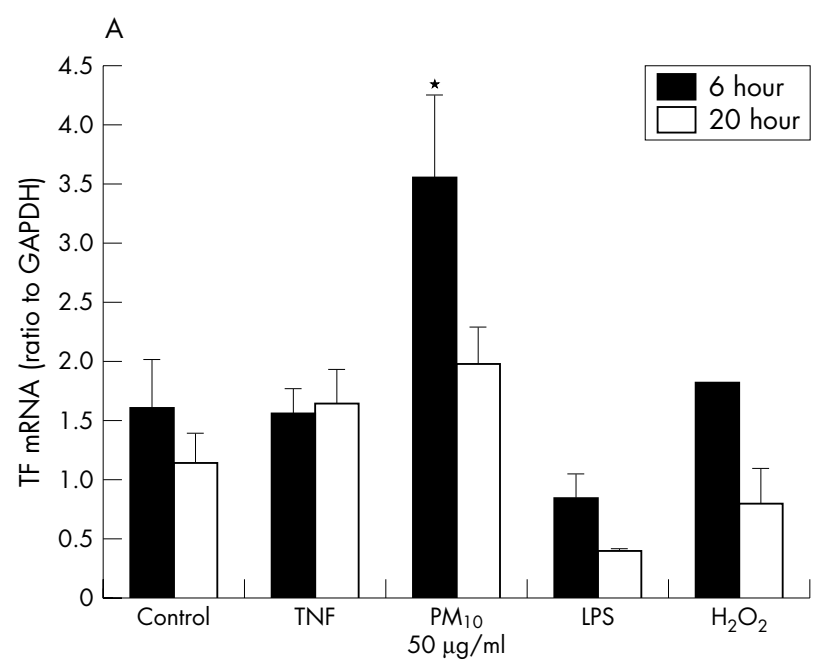

B B

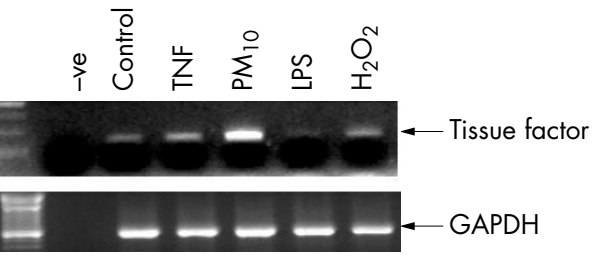

Figure 3 Macrophage tissue factor mRNA expression as determined by RT-PCR following 6 and 20 hours treatment with PM $\mathrm{PM}_{10}(50 \mu \mathrm{g} / \mathrm{ml})$, $\mathrm{TNF} \alpha(10 \mathrm{ng} / \mathrm{ml}), \mathrm{H}_{2} \mathrm{O}_{2}(100 \mu \mathrm{M})$, and LPS $(1 \mu \mathrm{g} / \mathrm{ml})$.

(A) Quantification of tissue factor RT-PCR bands by densitometry. Each bar represents the mean (SEM) from at least three separate experiments. ${ }^{*} p<0.05$. (B) A representative gel from macrophages treated for 6 hours. 
LPS. At 6 hours there was a significant increase in message with $\mathrm{PM}_{10}$ only (fig 3).

\section{HUVEC tPA mRNA and protein expression}

Vascular endothelium is the principal source of tPA. We wished to determine whether $\mathrm{PM}_{10}$ might affect vascular synthesis of tPA, should particles come into contact with endothelium within lungs, or systemically. Therefore we determined the tPA mRNA expression tPA and secretion by HUVECs treated for 6 and 20 hours with $\mathrm{PM}_{10}$ and LPS. At 6 hours $\mathrm{PM}_{10}$ reduced the expression of tPA mRNA (fig 4A) and to a greater extent than LPS treatment which also lowered tPA mRNA levels albeit not significantly. The tPA protein levels in culture medium were decreased at 4 hour $\mathrm{PM}_{10}$ treatment in a dose dependent manner, reaching significance at $100 \mu \mathrm{g} / \mathrm{ml}$ and also by $\mathrm{PM}_{10}$, LPS, and TNF at 20 hours (fig 4B).

HUVEC tissue factor mRNA and protein expression

Although vascular endothelial cells do not express TF in health, there is some evidence for TF expression in vitro, in response to agonists. Therefore we also investigated TF mRNA expression and protein released into culture medium from HUVECs treated with $\mathrm{PM}_{10}$ and LPS. At 6 hours, $\mathrm{PM}_{10}$ enhanced TF mRNA expression in a dose dependent manner (fig 5A); LPS treatment also increased TF mRNA expression. The TF protein levels in culture medium at 4 hours were also increased by $\mathrm{PM}_{10}$ but were no different from control at 20 hours (fig $5 \mathrm{~B}$ ).

\section{DISCUSSION}

Because of the link between particulate air pollution and acute cardiovascular events we wished to determine whether $\mathrm{PM}_{10}$ have potentially prothrombotic properties. First, we were able to show that supernatants from cultures of human macrophages exposed to $\mathrm{PM}_{10}$ contain procoagulant material. This property is not unique to macrophages, as a cell line of bronchial epithelial origin responded similarly. Furthermore, hydrogen peroxide exposure induced release of procoagulant material from these cells, whereas lipopolysaccharide did not. We employed a global coagulation assay in these experiments. A similar one stage clotting assay has been used previously to examine the coagulation enhancing effects of alveolar epithelial cells and macrophages from rats. $^{32}$ In that study the supernatants from rat epithelial cells were found to contain more coagulation enhancing activity
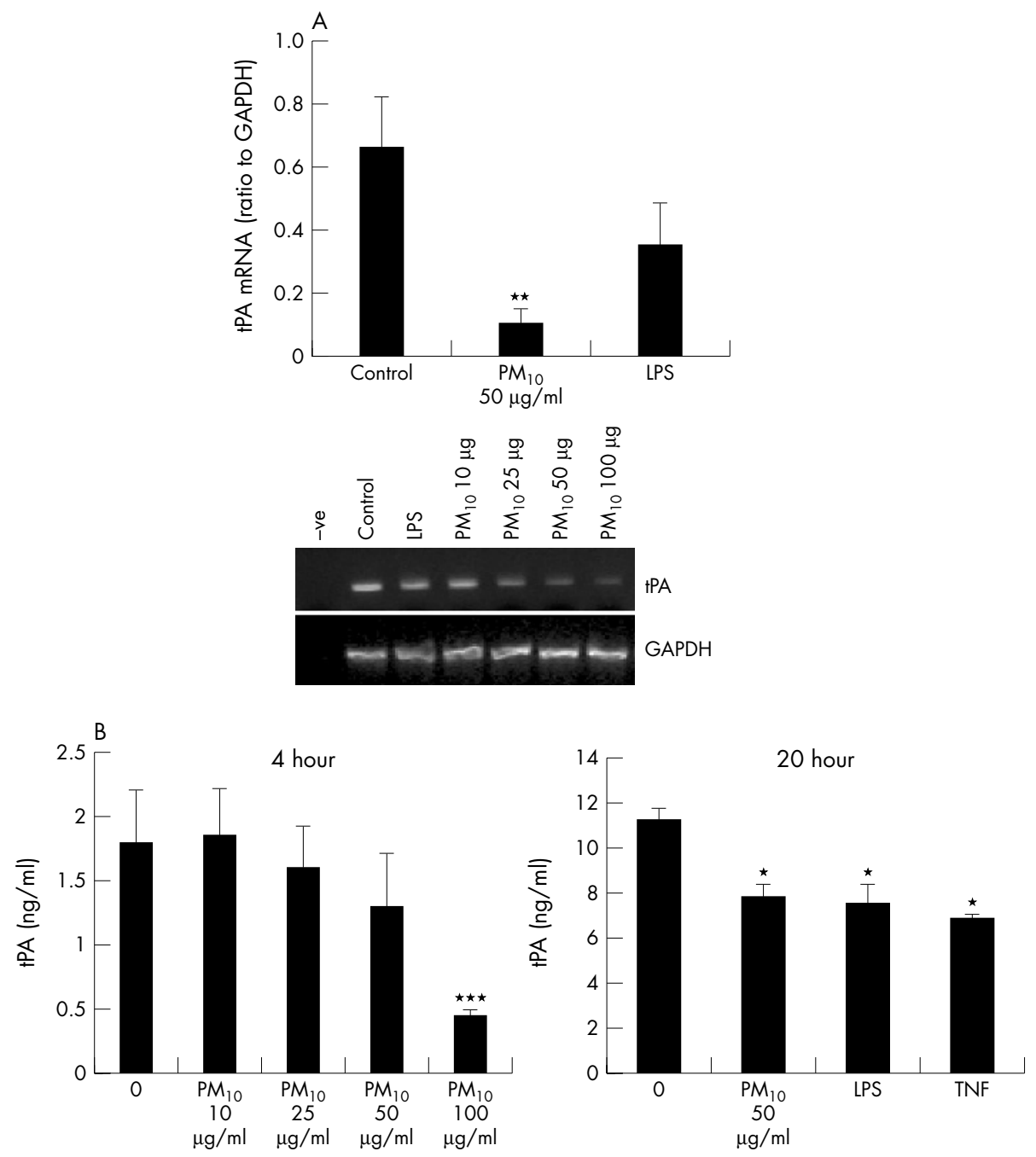

Figure 4 HUVEC tPA mRNA expression as determined by RT-PCR following 6 hours treatment with PM10 $(10,25,50$, and $100 \mu \mathrm{g} / \mathrm{ml}$ for dose response, $50 \mu \mathrm{g} / \mathrm{ml}$ for quantified histogram), TNF $\alpha(10 \mathrm{ng} / \mathrm{ml})$, and LPS (1 $\mu \mathrm{g} / \mathrm{ml})$. (A) Quantification of tissue factor RT-PCR bands by densitometry. (B) Protein released by HUVECs as determined by ELISA following 4 or 24 hours exposure. Each bar represents the mean (SEM) from at least three separate experiments. ${ }^{*} p<0.05,{ }^{* *} p<0.01,{ }^{* * *} p<0.001$. 
than isolated macrophages. However phorbol myristate acetate (PMA) was used as a stimulus and the effects of environmental particles were not considered.

In further experiments with macrophages we explored the nature of any procoagulant response to $\mathrm{PM}_{10}$. We found that these particles resulted in a significant increase in membrane surface exposure of anionic phospholipid, measured by annexin V binding. LPS was less potent, consistent with the results in the coagulation assay. In addition, tissue factor message was induced by exposure of macrophages to $\mathrm{PM}_{10}$ for 6 hours. Particle induced apoptosis in macrophages treated with environmental particles has been recently reported to be mediated by insoluble fractions of $\mathrm{PM}_{10}{ }^{33}$ Although this suggests that macrophage apoptosis, mediated by contact with the particles probably through phagocytosis, may cause enhancement of coagulation, we found that staurosporine, a potent inducer of apoptosis, did not significantly increase the coagulation enhancing activity of macrophage culture supernatants (data not shown). This is consistent with the findings of Barrowcliffe and colleagues, ${ }^{22}$ who showed that although the procoagulant activity of lymphoid cell lines was related to the expression of negatively charged phospholipids, this activity was not increased when apoptosis was induced by staurosporine. Anionic phospholipid exposure is an early event in apoptosis, preceding DNA fragmentation and loss of membrane integrity, ${ }^{34}$ and our data suggest that enhanced procoagulant activity is associated with this early phase, in macrophages exposed to particles, probably through the role of anionic phospholipid in the assembly of the tenase and prothrombinase complexes. ${ }^{34}$ Our data also suggest that there may be increased tissue factor synthesis by macrophages after $\mathrm{PM}_{10}$ exposure. Furthermore, tissue factor and anionic phospholipid act synergistically in activation of coagulation as the activity of tissue factor is modulated by the surrounding phospholipid, anionic phospholipids stimulating TF-VIIa activity. ${ }^{35}$

Our results indicate that pollutant particles and other insults such as oxidative stress could generate a procoagulant environment within the lungs. It is known already that fibrin deposition, a principal end point of coagulation activation, is a characteristic of inflamed and injured lung. Furthermore, it is now recognised that there are close links between inflammation and its mediators and blood coagulation. For example, inflammatory cytokines upregulate the expression of $\mathrm{TF}$, which initiates the coagulation cascade. ${ }^{36}$ It is of relevance, therefore, that we have shown that the synthesis and release of interleukin- 8 from macrophages in culture is also induced by exposure to $\mathrm{PM}_{10}$. This response was also seen in the other airways cells examined, although was less marked with the alveolar cell line. The level of response was generally comparable to that seen with other agonists (LPS, TNF, and $\mathrm{H}_{2} \mathrm{O}_{2}$ ). Our finding of the induction of IL-8 production by a bronchial epithelial cell line in response to $\mathrm{PM}_{10}$ is consistent with our own recent observations and those of others that various particulate pollutants induce a proinflammatory response in lung epithelial cells. ${ }^{11}$ 37-39 Interleukin-8 is a multifunctional cytokine with both proinflammatory and procoagulant properties. It is chemotactic for
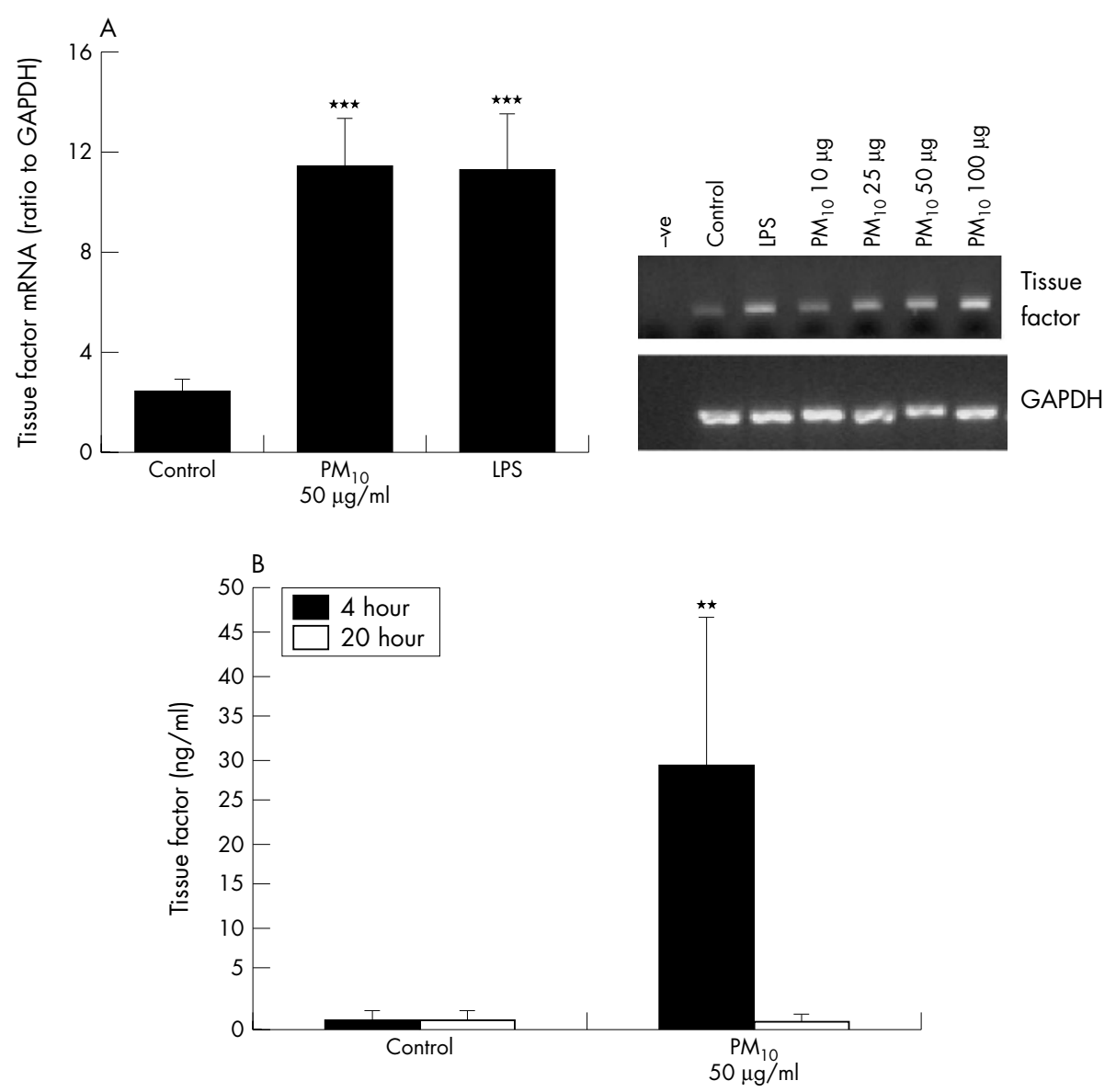

Figure 5 HUVEC tissue factor mRNA expression as determined by RT-PCR following 6 hours treatment with PM 10 (10, 25, 50, and 100 $\mu \mathrm{g} / \mathrm{ml}$ for dose response, $50 \mu \mathrm{g} / \mathrm{ml}$ for quantified histogram), and LPS $(1 \mu \mathrm{g} / \mathrm{ml})$. (A) Quantification of tissue factor RT-PCR bands by densitometry. (B) Protein released by HUVECs as determined by ELISA following 4 or 24 hours exposure. Each bar represents the mean (SEM) from at least three separate experiments. ${ }^{* *} \mathrm{p}<0.01,{ }^{* \star *} \mathrm{p}<0.001$. 
leucocytes and has been suggested to be an important participant in the cross-talk between the coagulation and cytokine cascades. ${ }^{40}$ It has been shown that thrombin acts as an inducer of IL-8 production in a monocyte cell line ${ }^{41}$ and also that IL- 8 causes a time and dose dependent increase in procoagulant activity of monocytes. ${ }^{17}$ The generation in the pulmonary environment of inflammatory cytokines is one mechanism whereby particle inhalation could exert a systemic effect. Tissue factor also initiates an inflammatory response. $^{42}$

Therefore, it seems likely that there is a synergistic role for pro-inflammatory and procoagulant factors which stimulate the activation and expression of the other. Different cell types produce different mediators to varying degrees in response to particles, and indeed are differentially exposed to particles. In this regard the combination of responses by different cell types within the complex milieu of the lung will be important in the overall resulting inflammation and procoagulant effect of particle exposure. There is precedence for a role of inflammation in enhancing a coagulation response in pneumonia patients ${ }^{43}$ and acute respiratory distress syndrome (ARDS). ${ }^{44}$

Another possible mechanism whereby inhaled particles could exert remote effects is through their passage into and distribution through the systemic circulation. It is recognised now that ultrafine particles, a component of $\mathrm{PM}_{10}$, can enter the systemic circulation in both experimental animals ${ }^{45}$ and man. ${ }^{46}$ This raises the possibility that the procoagulant effects of $\mathrm{PM}_{10}$ on macrophages might be relevant to thrombosis on atherosclerotic plaques. Macrophages are an important component of plaque, and tissue factor has been reported to be over-expressed in macrophages present in atherosclerotic plaques. ${ }^{47} 48$ Nemmar and colleagues ${ }^{49}$ have shown that blood removed from hamsters exposed to diesel particles has an enhanced ability to induce platelet aggregation.

In the light of the recent evidence that inhaled particles can enter the systemic circulation, we also postulated that particles could affect the functions of vascular endothelium. Although the concept that tissue factor can ever be synthesised by vascular endothelial cells in vivo has been challenged, in view of the likely catastrophic consequences, endothelial cells in culture do appear to be capable of expression of tissue factor when stimulated. We confirmed that LPS increases tissue factor message in cultured human umbilical vein endothelial cells. Furthermore, $\mathrm{PM}_{10}$ had a comparable effect and stimulated release of tissue factor into the culture supernatant. Perhaps of potentially greater pathophysiological significance, synthesis and secretion of the principal plasminogen activator, tPA, was inhibited in a dose dependent manner after exposure of umbilical vein endothelial cells to $\mathrm{PM}_{10}$. Whether these prothrombotic effects are present at the concentrations of particles found in vivo is open to question. There is recent evidence for particle mediated endothelial activation and for the procoagulative effects of systemic particle exposure. Particles, at a concentration relevant to the theoretical number of particles translocated to the bloodstream from a daily ambient particle exposure, introduced by intra-arterial infusion injection into the bloodstream of mice caused platelet accumulation, fibrin deposition, and fibrinogen expression in the liver. ${ }^{50}$ However, it is noteworthy that vascular endothelial cells can behave as non-professional phagocytes. This capacity could lead to concentration of particles in endothelium, as well as in macrophages in atherosclerotic plaque.

In conclusion, we have shown novel mechanisms whereby particulate air pollution may induce a procoagulant and proinflammatory response. Further studies should aim to define more precisely the relative contribution of anionic phospholipid exposure, apoptosis, and tissue factor synthesis and de-encryption, in the procoagulant activity associated with macrophage exposure to $\mathrm{PM}_{10}$.

\section{Authors' affiliations}

P S Gilmour, K Donaldson, W MacNee, Edinburgh Lung and the Environment Group Initiative (ELEGI)/Colt Laboratory, The University of Edinburgh, Department of Medicine and Radiological Sciences, Medical school, Wilkie Building, Teviot Place, Edinburgh, UK

E R Morrison, M A Vickers, I Ford, M Greaves, Haematology Unit, Department of Medicine and Therapeutics, Polwarth Building, Medical School, University of Aberdeen, Foresterhill, Aberdeen AB25 2ZD, UK C A Ludlam, Department of Haematology, Royal Infirmary of Edinburgh, Old Dalkeith Road, Edinburgh, UK

Funding: This work was supported by the British Lung Foundation, the Medical Research Council (UK), and the Colt Foundation

Competing interests: none declared

\section{REFERENCES}

1 Atkinson RW, Anderson HR, Strachan DP, et al. Short-term associations between outdoor air pollution and visits to accident and emergency departments in London for respiratory complaints. Eur Respir J 1999; 13:257-65.

2 Pope CA3, Burnett RT, Thun MJ, et al. Lung cancer, cardiopulmonary mortality, and long-term exposure to fine particulate air pollution. JAMA 2002;287:1132-41.

3 Pope CA3, Dockery DW, Spengler JD, et al. Respiratory health and PM10 pollution. A daily time series analysis. Am Rev Respir Dis 1991;144:668-74.

4 Dockery DW, Pope CA3, Xu X, et al. An association between air pollution and mortality in six U.S. cities. N Engl J Med 1993;329:1753-9.

5 Pope CA3, Verrier RL, Lovett EG, et al. Heart rate variability associated with particulate air pollution. Am Heart J 1999;138:890-9.

6 Daniels MJ, Dominici F, Samet JM, et al. Estimating particulate mattermortality dose-response curves and threshold levels: an analysis of daily timeseries for the 20 largest US cities. Am J Epidemiol 2000;152:397-406.

7 Seaton A, MacNee W, Donaldson K, et al. Particulate air pollution and acute health effects. Lancet 1995;345:176-8.

8 Peters A, Doring A, Wichmann HE, et al. Increased plasma viscosity during an air pollution episode: a link to mortality? Lancet 1997;349:1582-7.

9 Peters A, Frohlich M, Doring A, et al. Particulate air pollution is associated with an acute phase response in men; results from the MONICA-Augsburg Study. Eur Heart J 2001;22:1198-204.

10 Gilmour PS, Rahman I, Hayashi S, et al. Adenoviral E1A primes alveolar epithelial cells to PM(10)-induced transcription of interleukin-8. Am J Physiol Lung Cell Mol Physiol 2001;281:598-606.

11 Jimenez LA, Drost EM, Gilmour PS, et al. PM (10)-exposed macrophages stimulate a proinflammatory response in lung epithelial cells via TNF-alpha. Am J Physiol Lung Cell Mol Physiol 2002;282:237-48.

12 Ghio AJ, Kim C, Devlin RB. Concentrated ambient air particles induce mild pulmonary inflammation in healthy human volunteers. Am J Respir Crit Care Med 2000;162:981-8.

13 Seaton A, Soutar A, Crawford V, et al. Particulate air pollution and the blood. Thorax 1999;54:1027-32.

14 Suwa T, Hogg JC, Quinlan KB, et al. Particulate air pollution induces progression of atherosclerosis. J Am Coll Cardiol 2002;39:935-42.

15 Mukae H, Hogg JC, English D, et al. Phagocytosis of particulate air pollutants by human alveolar macrophages stimulates the bone marrow. Am J Physiol Lung Cell Mol Physiol 2000;279:924-31.

16 Mukae H, Vincent R, Quinlan K, et al. The effect of repeated exposure to particulate air pollution (PM10) on the bone marrow. Am J Respir Crit Care Med 2001;163:201-9.

17 Neumann FJ, OHt I, Marx N, et al. Effect of human recombinant interleukin-6 and interleukin-8 on monocyte procoagulant activity. Arterioscler Thromb Vasc Biol 1997; 17:3399-405.

18 Moll T, Czyz M, Holzmuller H, et al. Regulation of the tissue factor promoter in endothelial cells. Binding of NF kappa B-, AP-1-, and Spl-like transcription factors. J Biol Chem 1995;270:3849-57.

19 Elsayed YA, Nakagawa K, Ichikawa K, et al. Expression of tissue factor and interleukin-1 beta in a novel rabbit model of disseminated intravascular coagulation induced by carrageenan and lipopolysaccharide. Pathobiology 1995;63:328-40.

20 Ferro D, Basili S, Alessandri C, et al. Inhibition of tissue-factor-mediated thrombin generation by simvastatin. Atherosclerosis 2000;149:111-16.

21 Kunzelmann-Marche C, Satta N, Toti F, et al. The influence exerted by a restricted phospholipid microenvironment on the expression of tissue factor activity at the cell plasma membrane surface. Thromb Haemost 2000;83:282-9.

22 Barrowcliffe TW, Fabregas $\mathrm{P}$, Jardi $M$, et al. Procoagulant activity of $T$ lymphoblastoid cells due to exposure of negatively charged phospholipid. Thromb Haemost 2002;87:442-9.

23 Ananyeva NM, Kouiavskaia DV, Shima M, et al. Intrinsic pathway of blood coagulation contributes to thrombogenicity of atherosclerotic plaque. Blood 2002;99:4475-85

24 Gunther A, Mosavi P, Heinemann S, et al. Alveolar fibrin formation caused by enhanced procoagulant and depressed fibrinolytic capacities in severe 
pneumonia. Comparison with the acute respiratory distress syndrome. Am J Respir Crit Care Med 2000;161:454-62.

25 Kermarrec N, Zunic P, Beloucif S, et al. Impact of inhaled nitric oxide on platelet aggregation and fibrinolysis in rats with endotoxic lung injury. Role of cyclic guanosine 5'-monophosphate. Am J Respir Crit Care Med cyclic guanosine 5

26 Groeneveld AB, Kindt I, Raijmakers PG, et al. Systemic coagulation and fibrinolysis in patients with or at risk for the adult respiratory distress syndrome. Thromb Haemost 1997:78:1444-9.

27 Idell S. Endothelium and disordered fibrin turnover in the injured lung: newly recognized pathways. Crit Care Med 2002;30:274-80

28 Dahl OE. The role of the pulmonary circulation in the regulation of coagulation and fibrinolysis in relation to major surgery. J Cardiothorac Vasc Anesth 1997:11:322-8.

29 Gimbrone MA Jr, Cotran RS, Folkman J. Human vascular endothelial cells in culture. Growth and DNA synthesis. J Cell Biol 1974;60:673-84.

30 Donnelly SC, Strieter RM, Kunkel SL, et al. Interleukin-8 and development of adult respiratory distress syndrome in at-risk patient groups. Lancet 1993;341:643-7.

31 Snedecor GCW. Statistical methods. Ames, IA: lowa State University Press, 1974.

32 Gross TJ, Simon RH, Sitrin RG. Tissue factor procoagulant expression by rat alveolar epithelial cells. Am J Respir Cell Mol Biol 1992;6:397-403.

33 Soukup JM, Becker S. Human alveolar macrophage responses to air pollution particulates are associated with insoluble components of coarse material, including particulate endotoxin. Toxicol Appl Pharmacol 2001;171:20-6.

34 Tedgui A, Mallat Z. Apoptosis as a determinant of atherothrombosis. Thromb Haemost 2001;86:420-6.

35 Andree HA, Nemerson Y. Tissue factor: regulation of activity by flow and phospholipid surfaces. Blood Coagul Fibrinolysis 1995;6:189-97.

36 Esmon CT. Does inflammation contribute to thrombotic events? Haemostasis 2000;30(suppl 2):34-40.

37 Dick CA, Dennekamp M, Howarth S, et al. Stimulation of IL-8 release from epithelial cells by gas cooker PM (10): a pilot study. Occup Environ Med 2001;58:208-10.
38 Allermann L, Poulsen OM. Interleukin-8 secretion from monocytic cell lines for evaluation of the inflammatory potential of organic dust. Environ Res 2002;88:188-98.

39 Burvall K, Palmberg L, Larsson K. Effects by 8-bromo-cyclicAMP on basal and organic dust-induced release of interleukin- 6 and interleukin-8 in A549 human airway epithelial cells. Respir Med 2003;97:46-50.

40 Johnson K, Choi Y, DeGroot E, et al. Potential mechanisms for a proinflammatory vascular cytokine response to coagulation activation. $J$ Immunol 1998; 160:5130-5.

41 Suk K, Cha S. Thrombin-induced interleukin-8 production and its regulation by interferon-gamma and prostaglandin E2 in human monocytic U937 cells. Immunol Lett 1999:67:223-7.

42 Bokarewa MI, Morrissey JH, Tarkowski A. Tissue factor as a proinflammatory agent. Arthritis Res 2002;4:190-5

43 Schultz MJ, Levi $M$, van der PT. Anticoagulant therapy for acute lung injury or pneumonia. Curr Drug Targets 2003;4:315-21.

44 Welty-Wolf KE, Carraway MS, Ortel TL, et al. Coagulation and inflammation in acute lung injury. Thromb Haemost 2002;88:17-25.

45 Nemmar A, Vanbilloen H, Hoylaerts MF, et al. Passage of intratracheally instilled ultrafine particles from the lung into the systemic circulation in hamster. Am J Respir Crit Care Med 2001;164:1665-8.

46 Nemmar A, Hoet PH, Vanquickenborne B, et al. Passage of inhaled particles into the blood circulation in humans. Circulation 2002;105:411-14.

47 Kato K, Elsayed YA, Namoto M, et al. Enhanced expression of tissue factor activity in the atherosclerotic aortas of cholesterol-fed rabbits. Thromb Res 1996;82:335-47

48 Sueishi K, Ichikawa K, Kato K, et al. Atherosclerosis: coagulation and fibrinolysis. Semin Thromb Hemost 1998;24:255-60.

49 Nemmar A, Hoylaerts MF, Hoet PH, et al. Possible mechanisms of the cardiovascular effects of inhaled particles: systemic translocation and prothrombotic effects. Toxicol Lett 2004;149:243-53.

50 Khandoga A, Stampfl A, Takenaka S, et al. Ultrafine particles exert prothrombotic but not inflammatory effects on the hepatic microcirculation in healthy mice in vivo. Circulation 2004;109:1320-5.

\section{Register now!}

10th European Forum on Quality Improvement in Health Care

13-15 April 2005, ExCel Conference Centre, London

For further information on how to register please go to:

http://www.quality.bmipg.com 